\title{
Humour and intertextuality in online spoof news
}

\author{
Ksenia M. Shilikhina \\ Voronezh State University, Russia \\ shilikhina@,rgph.vsu.ru
}

\begin{abstract}
The paper discusses spoof news as a parody of the traditional genre of news and the role of intertextual references in the creation of the intended humorous or satirical effect. The study is based on the texts published by various online sources specialising in the production and spreading of spoof news. On the surface, the main aim of such non-bona fide pieces of news is not to misinform the readers, but rather to entertain them. However, along with entertainment, these texts also convey serious social implications. They implicitly undermine social norms and values and existing stereotypes about social roles and patterns of behaviour. The nonbona fide mode of such news can be signalled by a variety of intertextual references, e.g., fictional quotations, allusions to well-known texts, events or realia. The aim of the study is to demonstrate how these intertextual references create satirical effect and convey social criticism.
\end{abstract}

Keywords: news genre, spoof news, humour, social criticism, intertextual references.

\section{Introduction}

News as a trust-based account of what people need to know has always been a serious matter, since "those who provide news do more than tell daily stories; they frame and shape a common sense of the world, both distant and local" (Coleman et al. 2009: 7). It comes as no surprise that until recently humour and news were not viewed as closely related phenomena. However, the emergence of spoof news as a mock counterpart of the traditional news and its widespread dissemination online makes it necessary to study the interplay between the bona fide and non-bona fide modes of discourse in such texts and the carnivalesque transformation of the news genre that until recently was an example of pure bona fide public knowledge.

In her analysis of spoof news, Ermida (2012) develops a model with three components, namely an intertextual component with its structural and stylistic variations, a critical component, and a comic component consisting of lexical, pragmatic and rhetorical components. In this paper the focus is placed on the first and the second components. The aim of the present analysis is twofold: firstly, to demonstrate how various forms of intertextual references can be used to create humorous or satirical effect. Secondly, the study aims to show 
that these intertextual references can convey rather serious social implications with the aim to express criticism.

The paper is structured as follows: firstly, it briefly discusses the relations between different types of news, namely real news, fake news, and spoof news. Then it presents the data used in the study. Next, it describes how, by imitating formal properties of the bona fide news text, the hybrid genre of spoof news makes a parody of its bona fide counterpart. The study includes a description of the various types of intertextual references used in the nonbona fide news texts and their role in creating humorous or satirical effect. Finally, the paper analyses the implications of these texts and their relation to social values and boundaries.

\section{The issue of credibility: news, fake news, and spoof news}

Although misinformation in modern mass media is not a new phenomenon, for many the issue of people's trust in the news seems trivial: by default, news should normally be based on truth and real facts. However, in recent decades the factor of trust has been challenged by a manipulation technique referred to as fake news (Issers 2014; Rubin et al. 2016; Verma et al. 2017; Tandoc et al. 2018).

The Macmillan Dictionary Online (2009-2019) defines the adjective fake as "made to look like something real in order to trick people". In the same vein, researchers define fake news as "news articles that are intentionally and verifiably false, and could mislead readers" (Allcott \& Gentzkow 2017: 213). Because items of fake news are stories about events that never happened, researchers liken them to myths that exist online with the aim to mystify the readers (Issers 2014). Today fake news items are created predominantly in the bona fide mode of discourse and are spread intentionally mostly to misinform people or to distract their attention from existing problems. Consequently, the issue of credibility and the question of distinguishing between real news and fake news meant for intentional misleading of the readers are now widely discussed among journalists, politicians, mass media scholars and computer scientists (Holt 2007; Rubin et al. 2016; Tandoc et al. 2018), and in some countries (e.g. in Russia) spreading fake news can result in legal prosecution.

However, along with the bona fide fake news there exist satirical news, namely spoof news, the ultimate aim of which is to entertain the readers (Ermida 2012; Rubin et al. 2016). Just like fake news, they do not refer readers to any real fact or event. What makes items of fakes news and texts of spoof news different is that the latter describe situations which contradict our common sense and the readers get an immediate feeling that there is something odd about the event described (Simpson 2003). On the surface, pieces of spoof news imitate genre properties of a bona fide news text and, at the same time, contain various signals of humorous or satirical intention. Along with entertainment, another aim of such texts is to express implicit criticism of social norms, stereotypes, or events or to mock well-known people (e.g. politicians or celebrities) by putting them in rather absurd situations. This mockery places spoof news into the category of satire, parody, or irony (Simpson 2003; Rubin et al. 2016).

The texts of spoof news are produced and published online by numerous websites specifically devoted to this genre. To make their texts look more news-like, the majority of these websites imitate the structure of a bona fide news feed. However, it should be noted that some Internet sources explicitly mark their non-bona fide nature by putting a disclaimer (e.g. The Humortimes uses the phrase "This is a satirical news piece, just for fun, read at your own risk!"), or by labelling certain sections as "Satire", as does the Philippine site Superficial Gazette. Others still prefer to imitate 'normal' news feed with traditional subsections, e.g., "Politics", "Sport", "Science", "Society", etc. Being thematically structured, they may look 
pretty much like bona fide news feeds. What is common for all texts published on these sites is their entertaining nature: every text contains a variety of markers of the non-bona fide discourse mode.

The present study focuses on spoof news texts. In what follows, I will describe the samples of such texts used in the study and demonstrate how humorous or satirical effect can be created with various forms of intertextual references.

\section{Data and method}

The analysis is based on two datasets totalling 400 texts of spoof news written in English or Russian between 2012 and 2018. The first stage of compiling the samples involved choosing texts according to the language (Russian or English) and sorting them in groups according to the topic discussed. The texts were collected from a number of Internet sites in English and Russian: Smixer.ru, Lapsha.ru, Superficial Gazette of the Republic of the Philippines, The Humortimes and The Onion. The idea behind studying texts written in two languages was to see if there are any common generic features of such texts which are not specific to a particular language.

Each of the two samples contains 200 texts of 150-300 word length. In both samples the texts cover a variety of topics, e.g., politics, business, sport, social affairs, cooking, entertainment, celebrities, etc. Table 1 shows the distribution of texts according to their topic.

Table 1. Thematic sampling of texts.

\begin{tabular}{|l|r|r|}
\hline Topics & Texts in English & Texts in Russian \\
\hline Politics and economy & 50 & 37 \\
\hline Celebrities and entertainment & 42 & 48 \\
\hline Local affairs & 35 & 42 \\
\hline Sport & 40 & 38 \\
\hline Science and technology & 33 & 35 \\
\hline Total & 200 & 200 \\
\hline
\end{tabular}

After compiling the datasets, the next step of the study was the analysis of markers of the nonbona fide mode. The following markers were considered: intertextual references to real or fictional events, mentions of well-known people or precursor texts, familiar stylistic patterns of discourse, and wordplay. Further analysis of social implications conveyed in the texts included defining sources of incongruity and the targets of mockery.

The following Sections discuss the relations between humour and intertextuality and present the analysis of intertextual references that function as markers of the non-bona fide discourse mode.

\section{Spoof news as parody}

In Bakhtin's (1981) terms, spoof news is a clear example of a secondary genre: it demonstrates stylistic proximity to bona fide news texts, enriching them with multiple intertextual references and other markers of the non-bona fide mode of discourse. The presence of such markers suggests that spoof news texts mimic not only the genre of news itself, but also a gamut of antecedent discourses. In her analysis of linguistic properties of spoof news, Ermida terms the genre as "parodic satire" (Ermida 2012: 186) and describes it as 
"a parodic form (an intertextual game wherein two texts - the original one and the fake one are set against one another resulting in comic incongruity) with satirical content (i.e. with a critical intention of laying bare, by way of ridicule, the wrongs of politics and society)" (Ermida 2012: 191, emphasis in the original).

Parody as a type of discourse mirrors a primary genre and can come in many forms and guises (Dentith 2002). In Genette's (1997) taxonomy of textual relations, parody is labelled as hypertextuality: this is not intertextuality in its strict sense; rather, this is re-writing of another text within a certain genre frame. However, many researchers treat parody as a clear example of intertextual relation (Dentith 2002; Piégay-Gros 2007). According to Gray et al. (2009: 18), "[t]exts do not take on meaning for any reader in a vacuum. Rather, a reader will always make sense of texts relative to other texts, 'socially' or intertextually". Humour scholars note that "parody borrows formal characteristics of the original and varies the content to poke fun at the author" (Norrick 1989: 131). However, parody can be viewed not only as a way to mock, but also as an important discourse practice. According to Dentith (2002: 6), "parody forms part of a range of cultural practices, which allude, with deliberate evaluative intonation, to precursor texts". Besides keeping formal resemblance, parody necessarily contains intertextual references that remind the audience of precursor texts, familiar quotations or patterns of discourse. As the data demonstrate, just as other parodies, texts of spoof news relate themselves to bona fide news texts that precede them to play with norms and values in an evaluative way and use various types of allusions to familiar texts, events, people, social norms and values, as well as typical discourse patterns.

\subsection{Borrowed form: genre similarity as intertextual reference}

Online spoof news texts often imitate the genre of news by sharing some formal genre properties with bona fide news texts. Indeed, in many ways the texts of spoof news look like traditional pieces of news: they are relatively short texts which typically focus on current affairs. However, because the task of the writer is to look both credible and incredible at the same time, pieces of spoof news should recontextualise familiar features of the traditional news genre. Let us look at those elements of the texts which make them look more news-like.

To illustrate the main points and to increase their fake credibility, pieces of spoof news are often accompanied by thematically related photos. Alluding to the topics discussed, these photos catch readers' attention and shape their expectations. In many cases, references to real geographical locations or well-known people or social institutions are included in the texts to make them look more realistic and to designate the target of social criticism. The following example illustrates the case: ${ }^{1}$

\footnotetext{
${ }^{1}$ All Russian examples are translated by the author for the purposes of the present study. The links for the texts analysed here can be found at the end of the article.
} 


\section{(1) Правительство России будет усилено чернокожими легионерами}

03.02.14 19:23

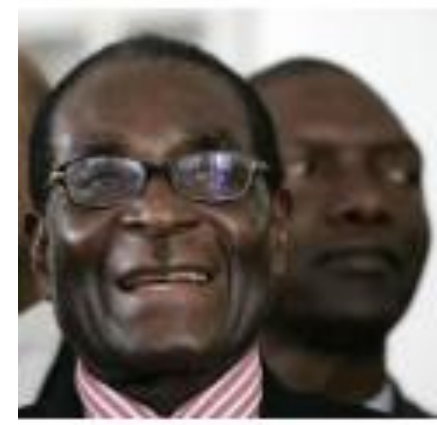

Два сильных африканских чиновника скоро укрепят российский кабинет министров. Об этом Smixer.ru сообщили в пресс-службе правительства.

По данным пресс-службы, контракт с легионерами уже подписан.

Главным трансфером этой зимы стала покупка Джанго Абачи из Гвинеи. Он займет место министра культуры, а Владимир Мединский пока отправится в кресло запасных.

Вторым приобретением кабмина стал молодой, но перспективный нигерийский чиновник Рафуго Апе. Он будет выходить на замену министру иностранных дел Лаврову, когда тому придется отправляться в зарубежные командировки.

\section{The Russian Government to be bolstered by two African officials} 03.02.14 19:23

Two strong African officials will soon bolster the Russian government. The information was passed to Smixer.ru by the press service of the government.

According to the representative of the press service, the contracts with the foreign officials have already been signed.

This winter the main transfer has become the acquisition of Jungo Abachi from Guinea. He will take the position of the Minister of Culture while Vladimir Medinsky will temporarily warm up the bench.

The second acquisition of the government is a young and promising Nigerian official Rafugo Ape. He will substitute for the Minister of Foreign Affairs Lavrov when the latter has to go abroad on business trips.

As can be easily noticed, features of the bona fide news are discursively integrated in the text of the non-bona fide fake news. The text mentions a trusted source of information (i.e. the press service of the Russian Government) and names of the two Russian ministers who are still in office; it makes reference to an official social institution (the Russian government) and contains a photo of two people, presumably the new officials from Africa. All these formal elements, traditionally present in bona fide news texts, contribute to the fake 'authenticity' of the spoof news.

Despite formal resemblance to the bona fide news text, the content of the news itself is rather absurd. Absurdity is the feature that clearly distinguishes spoof news from the bona fide news texts. In Example 1, the absurdity is created by reference to two incongruous scripts: "government and its duties" and "professional team sport". To refer to the script of "professional team sport", the writer uses terms and collocations which are typically encountered in the texts informing their readers about transfers of football or basketball players (this winter the main transfer has become the acquisition, warm up the bench, the 
second acquisition, young and promising). The two scripts are associated with two distinct sociolects and their mixing in the text leads to the emergence of what Attardo terms as register humour, defining registers as "language varieties associated with a given situation, role, or social aspect of the speaker's experience" (Attardo 1994: 230). The successful integration of these incompatible scripts can be possible only if a reader adopts a non-bona fide mode of interpretation. The intertextual references which evoke our knowledge about the two incongruous scripts are examples of a verbal technique widely employed by the genre of nonbona fide fake news to create humorous effect.

Example 2 exhibits similar formal resemblance to the bona fide piece of news: it mentions the names of politicians and geographical places, and refers to the real fact of the twin earthquakes which struck the Philippines on April $8^{\text {th }}, 2017$. The text is visually supported by joined-up photos of the vice-president of Philippines, a group of protesters carrying slogans, and a map on which the epicentre of the two earthquakes is marked.

\section{(2a) Duterte Supporters Blame Robredo for Earthquakes}

MANILA, PHILIPPINES - Angry supporters of President Rodrigo Duterte blamed Vice President Leni Robredo for the two earthquakes that occurred in Batangas on Saturday afternoon. The twin quakes, with measured magnitudes of 5.7 and 6.0, rocked Metro Manila and nearby provinces. In less than an hour, a crowd of about 2,000 Duterte supporters was assembled at Luneta (with the organisers claiming crowd numbers of more than 200,000), with angry chants blaming the Vice President as the cause of the earthquakes.

The reference to the disaster has a hyperlink to another Internet news feed where readers can get updated bona fide information on the disaster. The real news also contains maps showing the epicentres and spreading of the earthquakes and the opening part of the serious news contains details about the magnitude of the earthquake that are later echoed in the spoof news text:

\section{(2b) Twin earthquakes rock Metro Manila, nearby provinces}

Batangas is the epicenter of both earthquakes, which measured magnitude 5.6 and 6.0, respectively

MANILA, Philippines (7th UPDATE) - Twin earthquakes rocked Metro Manila and nearby provinces on Saturday afternoon, April 8.

The Philippine Institute of Volcanology and Seismology (Phivolcs) said a magnitude 5.6 quake first struck at 3:07 pm, off Mabini, Batangas. The United States Geological Survey (USGS) put it at 5.7. The first quake was then followed by a magnitude 6.0 tremor at $3: 09 \mathrm{pm}$, also in the same area, according to Phivolcs. USGS earlier said this tremor had a magnitude of 5.9.

However, further development of the two texts takes different directions. While the bona fide news continues with the detailed description of the disasters, the spoof news adds another script by switching to politics and suggests an obviously absurd explanation for the disasters. In the spoof news, the interplay between the bona fide and non-bona fide modes is created by suspending reality: our common sense tells us that no one can cause or stop a natural disaster by force of will.

As these examples demonstrate, on the surface the language and style of spoof news resemble those of typical news items. At this point, we can say that formal intertextuality has become a specific technique of text creation. By using references to a variety of recognisable realia, the authors imitate the bona fide news format, and for gullible readers this formal similarity can be deceiving. Formal resemblance of the bona fide and non-bona fide news texts is just one possible type of intertextuality. There are also other types, e.g., fake quotations and wordplay, which also function as markers of the non-bona fide intention of spoof news. 


\subsection{Borrowed words: Allusions, fake voices, and word play}

In his discussion of parody as a specific type of discourse, Dentith (2002: 5) defines intertextuality as "the interrelatedness of writing, the fact that all written utterances - texts situate themselves in relation to texts that precede them, and are in turn alluded to or repudiated by texts that follow". Following this logic, we can safely assume that quotations are the most obvious signs of linguistic interaction between texts. However, in the case of spoof news quotations can also be fictional: they only imitate or mock familiar patterns of discourse or "voices" of those to whom fictional quotations are ascribed. Sometimes they can even refer the readers to easily recognised clichés, as in the Example 3:

\section{(3) Duterte Supporters Blame Robredo for Mayon Eruption}

QUEZON CITY, PHILIPPINES - Mayon's eruption is the latest step in a conspiracy to "destabilise the Duterte Administration", according to supporters of President Rodrigo Duterte.

A small group of protesters gathered outside the head office of Vice President Leni Robredo in Quezon City, calling on her to stop the eruption that led to the evacuation of at least 81,000 residents.

The phrase "destabilise the Duterte Administration" is an example of utterance echoing stereotypical pro-government political discourse characteristic of many dictatorship regimes. It relates the spoof news to instances of anterior official pro-presidential discourse. References to the attempts to destabilise the situation are frequently used as a cliché by mass media with the aim of criticism of political opponents. Humorous effect emerges as a result of interplay of different communicative layers: by putting the phrase within the absurd context, the writer highlights the gap between reality and parody and expresses criticism of the authorities who tend to blame anyone but themselves for the economic and political crisis in the country.

The next example contains fictional quotations ascribed to Donald Trump who is famous for expressing radical ideas in public by using a rather specific manner of speech which sometimes deviates from what is normally expected from a politician:

\section{(4) Trump Calls Secret Meeting to Power-up for Next Summit}

By Diane de Anda, June 17, 2018

Trump proposes ways to increase his bargaining power ahead of the next summit with Kim Jongun.

A White House informant has just leaked information regarding a secret meeting President Trump had this morning regarding the next summit with Kim Jong-un. He met with Jeff Sessions, Kirstjen Nielsen (head of Homeland Security), Mitch McConnell, Secretary of State Mike Pompeo, and Supreme Court Justices Gorsuch, Alito and Thomas.

Trump began by stating how "enlightened" he had become during his meeting with Kim Jong-un, and how much he had learned about "what it takes to be a strong leader and make sure that your agenda is accomplished. I have to admit, I was impressed and more than a little envious..."

He then turned to the Supreme Court Justices and to McConnell. "I don't care if it's by legislation or executive order, we need a way to reel in that crazy First Amendment". The Supreme Court Justices nodded their heads in agreement, except for Thomas who was just nodding in his sleep.

The words attributed to Trump come into contradiction with what is expected both ideologically and stylistically: the President is the one who is supposed to observe the Constitution, not to call it crazy. Stylistically, while the fictional quotations in the second paragraph belong to the official style, the third paragraph is a clear example of colloquial style - something that is not generally expected in the public discourse of a political leader of the highest rank. This stylistic contrast is a rather frequent way of producing humorous effect. In the text above, it mimics Trump's harsh manner of speech and the contrast between high and 
low styles of public speech mocks typical features of presidential discourse and undermines the seriousness of the situation. The incongruity of stylistic resources produces stylistic/register humour (Archakis et al. 2014, 2015; see also Attardo 1994 in Section 4.1) and the president is characterised as communicatively incompetent (Archakis et al. 2015) which, in turn, marks the criticism of Trump's extravagant behaviour in public.

A close example of using fake quotations to satirise a political leader and his actions is the news about the reaction of the President of Russia to the confirmation made in the Mueller Report on Putin not being guilty of attempting to interfere in the 2016 elections in the USA. The issue was heavily reported internationally in mass media and caused another round of tension between the two countries:

\section{(5) Shocked Vladimir Putin Slowly Realising He Didn't Conspire With Trump Campaign 'Who The Hell Was I Working With Then?' Asks Russian President} MOSCOW - Saying that he had been "totally blindsided" by the revelations from the recently released findings of the Mueller investigation, a shocked Vladimir Putin reportedly came to the realisation Tuesday that he didn't conspire with Donald Trump's 2016 presidential campaign after all. "What the hell? I worked so hard on this - if I wasn't colluding with the Trump campaign, who the hell was I colluding with?" said the dumbfounded Russian president, growing increasingly angry as he scrolled through his email inbox and recounted his numerous efforts at covert communication with individuals who he had thought were high-ranking Trump officials, but now he suspected were bots or anonymous internet trolls. "Man, it seemed so legit. I can't believe I let myself get conned like this. I spent so much time emailing back and forth with DonaldTrump46@hotmail.com about compromising the democratic voting process, and now it turns out it was all fake? And we spent so much time gathering all that kompromat on the wrong people. Goddammit, I feel like I've wasted my life". At press time, Putin was frantically doublechecking that Russia had assisted in propping up a dictator in Syria and not some other country.

The text has as its target the events which caused another spiral of tension between Russia and the USA. The mock quotation ascribed to Putin demonstrates abnormal political behaviour as something that seems to be the normal practice for him. Fictional quotations which contain colloquial words, again, are stylistically inappropriate for the President: these words undermine the widespread stereotype of presidential behaviour and denigrate the political leader. The fake voice of the President of Russia portrays him as a gullible person outperformed by some unknown internet pranksters. The play between high and low styles along with the juxtaposition of factual and fictional elements create the comic effect and mock the real situation.

In general, political satire in the form of spoof news has become a popular way of expressing critical stance. However, fictional quotations can be attributed not only to politicians or celebrities, but also to ordinary people who can also be fictional characters of spoof news stories. The following spoof news text cites words belonging to a father who comments on his failed attempt to explain the basic concepts of baseball to his teenage son:

\section{(6) Flustered Father Struggling To Answer All Of Son's Questions About What Catch Is}

ALBANY, NY - Feeling completely unprepared for such a difficult conversation, local father Michael Dorgan was reportedly struggling Monday to answer all his son's questions about what a catch is. "God, this so awkward, he was watching the Super Bowl last night, and now he has so many questions and I can't describe how it works", said Dorgan, who admitted to stammering his way through an uncomfortable 10-minute explanation of what a football move is. "I tried bringing out a football to show him what maintaining possession means, but I think it just confused him more. And there was this painful silence after he asked about controlling the ball long enough to become a runner. How do you explain something as complicated and mysterious as that to your 
son? I wish he just asked his mother". Dorgan added that something as important and complicated as what a catch is should definitely be taught in school.

The father's verbal behaviour imitates the discourse pattern traditionally used by adults who face the need to talk to a child on a sensitive topic or a taboo theme. The difficulty of explaining such issues is the real target of irony here: although on the surface the text is about sport, the target of the joke is the culturally supported inability to discuss such themes. As the quotation goes on, the father expresses his wish to address the question to the mother or discuss it in the school classroom - which is what often happens when an adult finds it impossible to overcome embarrassment and discuss a sensitive topic openly.

Why do spoof news texts use fictional quotations so lavishly? As Scollon (2004: 150) argues, "journalists use the linguistic means of reported discourse to delegate principalship or the responsibility for what is said to the newsmakers". Also quotations allow the writers to incorporate more intertextual references by introducing other voices in the text, and some of them may sound rather absurd. Stylistic resemblance of the absurd utterances to their bona fide counterparts makes it easier for the readers to recognise the target of criticism.

Another type of intertextual reference commonly found in spoof news pieces is the allusion to well-known precursor texts, sometimes with minor changes in them. The following example is an excerpt taken from the text titled "Vertically Challenged Putin Demands World Leaders Greet Him on Their Knees". It tells a story about Putin being not a very tall person, to order for other world leaders to greet him standing on their knees. The absurdity of the situation is further increased by the following passage:

\section{(7) Vertically Challenged Putin Demands World Leaders Greet Him on Their Knees}

Ascending his high horse, Putin hummed a few bars of what he said would be Russia's new national anthem, Twinkle, twinkle little Tsar.

References to the high horse and the little Tsar satirise the ambitions of the Russian President to retain his seat at whatever cost and play the key role in the world of politics. These implicit references to Putin's ambitions are also paralleled to his physical height hinting at the low value of these ambitions on the world political scene. The 'upgrade' of a well-known children's song to the status of a national anthem with a minor change in lyrics becomes yet another source of satire.

The texts of spoof news may also refer to important ideas or real events, and their appearance in absurd contexts evokes an incongruous script and becomes the marker of the non-bona fide mode. The following passage contains several signals of irony, one of which is the reference to the concept of "the new world order":

(8) Trump closed the session by handing out boxes of Happy Meals with the yellow logo smile replaced by the word "Trumptopia" above his own smiling face and these words beneath it: "Welcome to the New World Order".

The phrase Welcome to the New World Order is a hyperlink to another piece of news published by The Humortimes - the above-mentioned spoof news titled "Vertically Challenged Putin Demands World Leaders Greet Him on Their Knees" (example 7). Apart from direct reference to another piece of spoof news, this phrase contains an implicit reference to the so-called conspiracy theory and/or the idea of any historical period that faces dramatic changes in the balance of political power.

Another marker of the mocking nature of the text is the nonce word "Trumptopia" - an example of wordplay. The nonce word Trumptopia is an easily recognised contamination of the last name of the current American President and the noun utopia. The newly coined word 
creates a mental space which combines our knowledge about Donald Trump's political views and the genre of utopia and implies the idea of poor relation between ideas publicly expressed by the American President, on the one hand, and reality, on the other.

Wordplay can be listed as a yet another way of referring to another text or multiple texts. This type of allusion allows the writer to creatively refer to multiple precursor ideas or realia. In the following example, the prefix nano- echoes the fashion that exists in the Russian advertising discourse to add it to the names of the products (e.g. nano-socks) to make them look more technologically advanced and more prestigious:

\section{(9а) Российские ученые представили публике новое изобретение}

Новую разработку в области пищевого производства представили на днях российские ученые. Презентация нанопельменей, которые не производят брызг при погружении в кастрюлю, состоялась в рамках деловой программы всероссийского форума «Еда и нанотехногии», прошедшего в Москве в отеле Four Seasons...

Нанопельмени оказались достойными, отсутствие брызг при готовке приятно порадовало.

\section{Russian Scientists Demonstrated Their New Invention to the Public}

A new product of the food industry was introduced by Russian scientists the other day. The presentation of nano-dumplings, which do not splash when being loaded in the cooking pan, was held as part of the business programme of the all-Russia forum "Food and Nanotechnologies" in Moscow at the "Four Seasons" hotel...

Nano-dumplings were quite good, and the absence of splashes in the process of cooking was a pleasant surprise.

The humorous effect of the text is triggered by the word нанопельмени 'nano-dumplings'. The apparent absurdity of the new 'invention' mocks the desire to present common things as technologically advanced to deceive gullible customers. Wordplay in this text is supported by other types of intertextual references so that a more complex conceptual structure can be formed in the reader's mind. The situation in the short reportage gets more and more carnivalesque when the narrator quotes the inventor's words about studying diving:

(9b) Мы попросили производителя поделиться секретом, как удалось добиться полного отсутствия брызг? «Все дело в форме, - пояснил главный технолог компаниипроизводителя нанопельменей Иван Вуснов. - Мы наблюдали за спортсменами по прыжкам в воду, и сделали наши пельмени такой же формы».

We asked the manufacturer to share a secret how they had managed to eliminate splashes. "It all has to do with the shape, explained the chief engineer of the manufacturer, Ivan Vusnov. We had been watching the divers and then produced nano-dumplings of the same shape".

The resulting conceptual structure includes our knowledge about two incongruous scripts: the culinary dish and diving. Apparently, these scripts do not have much in common: the only component they share is water, which functions as the operating environment for both cooking and diving. However, the combination of other components produces an absurd conceptual structure and comic effect emerges.

As these examples demonstrate, spoof news can use various kinds of intertextual references to create new conceptual structures in which the story being told contradicts our common sense or general knowledge about the world. Apparently, this usage is not just a means of entertainment, but also a signal of implicit meaning. Let us now turn to the question of what sort of an implicit meaning can be transmitted in spoof news. 


\section{Social implications of spoof news texts}

It is a well-known fact that humour and laughter are tools for reflecting upon or even challenging social norms and values (Kuipers 2008). Along with being funny, even the most absurd pieces of non-bona fide fake news will tell us something about social values, shared interests and expectations, and make important cultural statements. These texts allude to a range of cultural practices and social norms, and the non-bona fide mode allows for carnivalesque expression of mock or disrespect of particular people or events.

Politics is, perhaps, the most obvious sphere of criticism. As examples (1-5) above demonstrate, in spoof news the critical evaluation of political actions and international relations is achieved through the reframing of current situations. However, pieces of spoof news can act as criticism of rather serious social issues that do not belong to the sphere of politics. The following translation of a Russian text is a mixture of entertainment and references to the current economic situation in Russia. The news mocks the wide gap between the richest and the poorest people that exists in modern Russia.

\section{(10) В оборот выпустят купюру в миллион рублей}

Миллионерам жить станет проще

Новая купюра, номинал которой составит один миллион рублей (1 000000$)$, может появиться в России осенью 2017 года. Об этом Smixer.ru сообщила председатель Центрального банка РФ Эльвира Набиуллина.

По словам спикера, необходимость появления новой купюры назрела давно. «Знаете, у нас люди не доверяют банкам, особенно в кризис, поэтому до сих пор многие предпочитают расчеты наличкой, - пояснила Эльвира Набиуллина, - а рассчитаться за квартиру или дорогой автомобиль наличными очень непросто».

Для того, чтобы упростить проведение операций с крупными суммами, было решено ввести в оборот купюры номинальной стоимостью в 1 миллион рублей. Подобные купюры выйдут в оборот в ограниченном количестве. Пока точно неизвестно, сколько их будет. Но, скорее всего, подержать в руках бумажку достоинством в миллион смогут далеко не все граждане России.

Зато можно хотя бы приблизительно представить, как будет выглядеть ценная купюра. Размер миллиона рублей в бумажном эквиваленте будет больше, чем у других. Ее планируется сделать разноцветной - цвета российского флага (синий, белый и красный) будут градиентно перетекать друг в друга. На фоне планируется напечатать рисунок, символизирующий исконно русские ценности - храм, березки и бескрайнее поле с васильками.

Защита от подделок будет отличаться от всех применявшихся ранее. «Это будет что-то, что совершенно невозможно будет скопировать и воспроизвести», - пообещала Эльвира Набиуллина.

Теоретически по законам РФ с купюрой в 1 миллион рублей можно будет придти в «Пятерочку» за хлебом и там не смогут отказать в том, чтобы принять эти деньги и выдать сдачу. Но, фактически, по словам Эльвиры Набиуллиной, такая ситуация исключена. «Люди, владеющие такими деньгами, не будут ходить с ними за хлебом», - заявила эксперт (Smixer.ru).

\section{A 1000000 Rouble banknote to be released}

The life of millionaires will be easier

A new 1000000 roubles banknote is likely to be released in Russia in the autumn of 2017. The news was confirmed to Smixer.ru by the Head of the Central Bank of Russia Elvira Nabiullina.

According to the official, the need for a new banknote is long overdue. "You know, people do not trust banks, especially in the crisis period, so a lot of people prefer to use cash", explained Elvira Nabiullina. "And to pay for a new apartment or a new luxury car with cash is not that easy". 
To make operations with large sums of money easier, it was decided to release banknotes with the nominal value of 1 million roubles. There will be a limited edition of such banknotes. So far, no one knows exactly how many of them will be printed. However, not all citizens of Russia will be able to hold a 1000000 note in their hands.

However, one can imagine what the new banknote will look like. The size of the paper banknote will be a bit larger than the size of other banknotes. It is planned to be made multicoloured with the colours of the Russian flag (blue, white and red) gradually changing into each other. In the background there will be images symbolising indigenous traditional Russian values - a cathedral, birch trees and a boundless field of cornflowers.

The protection against forgery will be totally different from all previously used methods. "It will be something totally impossible to copy or simulate", promised Elvira Nabiullina.

Theoretically, according to Russian laws, it will be possible to go to "Piatiorochka" with a 1million banknote to buy bread, and the shop will not be able to refuse to take the money and give change. Yet, in fact, according to Elvira Nabiullina, this situation is impossible. "People who have these banknotes, will not go to pay for bread with them", said the expert.

The text contains a range of intertextual references which can be easily recognised by those who live in Russia: the name of Elvira Nabiullina, who is the Head of the Central Bank of Russia, is frequently mentioned in official TV news programmes; "Piatiorochka" is a large chain of popular cheap supermarkets all over the country; a set of mentioned visual images including a church, cornflowers, and birch trees refers the readers to stereotypical symbols of traditional Russian countryside scenery often mentioned in folk songs and lyrics. There are also fictional quotations which, just as in the examples above, create two contrasting perspectives (cf. Kotthoff 2002): the explicit official perspective vs. the implicit critical one. Nabiullina' fictional words serve as an intertextual reference to the propaganda which has been regularly reproduced by the state-run mass media. The people are persuaded that the economic situation in the country is constantly improving and that the standards of living are on the rise. By mentioning the cheap chain supermarket, the spoof news just for a short second "equals" the richest and the poorest, as if these people could share the same routine. However, the last fictional quotation illustrates the social conflict between the rich minority who can afford to buy property and luxury cars on a daily basis, and the vast majority of Russians who can only afford to buy food in the cheapest supermarkets. The last quotation also hints at the cynicism of Russian authorities who prefer not to recognise the economic crisis in public and keep talking about the improving situation.

Example (11) is an instance of mocking a specific social problem in Russian society - the large number of divorces and conflicts in families. With its allusion to the practice of annual prolongation of other social duties (e.g. health or car insurance), the text of the news parodies a particular set of social circumstances and reframes our knowledge about marriage as a social partnership, as in the text it becomes subject to the state scrutiny:

\section{(11) Брак нужно будет продлевать каждый год}

\section{Чиновники нашли средство укрепления семейной жизни}

В России собираются ввести новое правило. С нового года всем супругам придется каждый год подтверждать свой статус. Это нововведение призвано укрепить институт семьи и брака в нашей стране. Корреспонденту Smixer.ru удалось первым узнать подробности.

Мы обратились с вопросами к инициатору нового законопроекта - председателю Комитета Государственной Думы по вопросам семьи, женщин и детей Тамаре Васильевне Плетнёвой.

«Сейчас в России много проблем с семейной жизнью. Супруги остаются в браке только на бумаге, а фактически уже таковыми не являются. Но нам приходится с ними работать, потому что официально они все же числится супругами. А это неправильно. У нас и так большая нагрузка на наш комитет. Мы не можем еще заботиться о всяких иждивенцах. 
Поэтому мы решили, что пусть все каждый год подтверждают свой супружеский статус. Пусть приходят, сдают тесты, и мы будем смотреть, действительно ли они являются супругами. И по результатам будем решать, продлевать ли брак или нет», - пояснила Тамара Васильевна.

Новый закон может вступить в силу уже в начале 2019 года. Так что, уже в следующем году все супруги будут обязаны пройти тест на продление семейной жизни (Smixer.ru).

\section{Marriages to be prolonged annually \\ Officials found a means to reinforce family life}

A new rule is to be introduced in Russia. Starting from the upcoming year, all spouses will have to confirm their marital status annually. This novelty is aimed at the reinforcement of marriage as a social institution in our country. The correspondent of Smixer.ru was lucky to get the details first. We addressed several questions to the initiator of the draft of the new law - the Chairperson of the Family, Women and Children Committee of the State Duma Tamara Vasilievna Pletneva.

"There are a lot of problems with family life in Russia now. Spouses retain their marital status only formally, while in fact they do not lead a family life. And we have to work with such people, since they are officially married. Yet, this is incorrect. There is a huge workload on our Committee and we cannot take care of various social dependents. That is why we have decided that all people should confirm their spousal status annually. They should come, take tests and we will decide if they are real husbands and wives. According to the results of their tests we will make a decision whether to prolong their marriage or not", explained Tamara Vasilievna.

The new law may officially be of effect at the beginning of 2019. So, next year all married people will be obliged to take a test to prolong their family life.

The text undermines our belief in marriage being a personal matter. Fake quotations ascribed to real people mark the conflict between people's private life and the desire of state officials to control every step of the citizens. The apparent absurdity of the situation echoes current attempts of the Russian authorities to impose legal constraints on people's privacy and the idea of total control becomes the target of mockery. This text also reminds the older generations of Russian readers of the Soviet times when divorces were subjects of public discussions at workplaces and people going through a divorce were criticised by the community. In a situation when direct public criticism of the authorities is not allowed, spoof news with its apparent absurdity becomes an option for expressing discontent.

The text contains a large fictional quotation ascribed to the member of State Parliament. The style of the quotation brings the official discourse to the point of absurdity, thus creating humorous effect. To understand the criticism behind the quotation one should know that since 2012 the Russian State Duma has been passing laws which contradict both the Constitution and the common sense (for instance, the infamous "Dima Yakovlev's law" forbidding foreigners to adopt children from Russian orphanages or the law that bans public protests). Since 2012, the number of such laws has increased dramatically. Commenting on the situation, one of the leading TV journalists Vladimir Pozner called the State Duma Gosudarstvennaya Dura (literally 'The State Fool') and the Parliament also got the nickname "the crazy printer". In this context, the idea of passing a law that would regulate marital status seems in line with the other laws passed by the State Duma.

In general, examples (10) and (11) are signs of political mistrust and disappointment that, despite what official propaganda says, are common in the modern Russian society.

The examples demonstrate that spoof news can address a variety of social issues with the aim to express critical stance towards the authorities. These findings are in accordance with the idea that

Humour is a quintessentially social phenomenon. Jokes and other humorous utterances are a form of communication that is usually shared in social interaction. These humorous utterances are 
socially and culturally shaped, and often quite particular to a specific time and place. And the topics and themes people joke about are generally central to the social, cultural and moral order of a society or a social group.

(Kuipers 2008: 361)

Humour encourages reflection upon existing norms and invites criticism. According to Bakhtin (1981: 3), "[i]t is precisely laughter that destroys the epic, and in generally destroys any hierarchical (distancing and valorised) distance". Usually the sustainability of existing norms and values is 'tested' by applying them to new, often absurd circumstances. In this context, various intertextual references in the spoof news texts function as implicit expression of discontent with the current situation.

\section{Conclusion}

Historically, the genre of spoof news has emerged as a mocking echo of traditional news. Being a secondary genre, the non-bona fide version thrives on intertextuality and overlapping voices of the writer and real people or fictional characters, exhibiting both the derivational formal resemblance and the co-presence of other texts in the form of fake quotations, wordplay or references to well-known events or social norms and values.

While formal resemblance is needed to increase the similarity of the text (allowing the text 'to pretend' to be a real piece of news), various forms of intertextual references within the text often function as markers of the non-bona fide mode. At the same time, intertextual markers function as a discursive technique allowing the writer to convey information about ongoing social conflicts in an implicit form. While texts of spoof news function primarily as a source of entertainment, intertextual references allow these spoof news texts to function as tools for conveying a particular stance and expressing evaluation of current events. With the help of specific contextualisation strategies social roles and stereotypes (e.g. of journalists, sportspersons, politicians) are imitated and official discourse is ridiculed: the writers use typified reported speech and quotations, they explicitly refer to existing places, social institutions or events.

Texts of spoof news also demonstrate a new type of intertextuality, namely, fake intertextual references. Absurd quotations, ascribed to political leaders, celebrities or unknown people mock personal or habitual discourse practices.

As the analysis shows, the functions of allusions range from the imitation of the genre to faking specific discourse practices or habitual forms of language use. All in all, the multiplicity of references, including fake ones, and possible interpretations is characteristic of satirical spoof news. Thus, the appreciation of humour largely depends on the reader's ability to recognise intertextual references which function as signals of non-bona fide intention of the spoof news. Because these references can take various forms, they can be hard to recognise. Consequently, those unable to establish cross-textual reference fail to recognise humour or irony and tend to interpret the news in the bona fide mode.

\section{References}

Allcott, H. \& Gentzkow, M. (2017). 'Social media and fake news in the 2016 Election'. Journal of Economic Perspectives 31 (2), pp. 211-236.

Archakis, A., Lampropoulou, S., Tsakona V. \& Tsami, V. (2014). 'Linguistic varieties in style: Humorous representations in Greek mass culture texts'. Discourse, Context and Media 3, pp. 46-55. 
Archakis, A., Lampropoulou, S., Tsakona V. \& Tsami, V. (2015). 'Style and humour in Greek mass culture texts', in Brzozowska, D. \& Chłopicki, W. (eds.), Culture's Software: Communication Styles, Newcastle upon Tyne: Cambridge Scholars Publishing, pp. 16-38.

Attardo, S. (1994). Linguistic Theories of Humour. Berlin \& New York: Mouton de Gruyter.

Bakhtin, M. (1981). The Dialogic Imagination (M. Holquist, ed.). Austin: University of Texas Press.

Coleman, S., Anthony, S. \& Morrison, D. (2009). Public Trust in the News: A Constructivist Study of the Social Life on the News. Oxford: The Reuters Institute for the Study of Journalism, University of Oxford.

Dentith, S. (2000). Parody: The New Critical Idiom. London: Routledge.

Ermida, I. (2012). 'News satire in the press: Linguistic construction of humour in spoof news articles', in Chovanec, J. \& Ermida, I. (eds.), Language and Humour in the Media, Newcastle upon Tyne: Cambridge Scholars Publishing, pp. 185-210.

Genette, G. (1997). Palimpsests: Literature in the Second Degree. Lincoln: University of Nebraska Press.

Gray, J., Jones J. P., \& Thompson, E. (2009). 'The state of satire, the satire of state', in Gray, J., Jones, J. P. \& Thompson, E. (eds.), Satire TV: Politics and Comedy in the Postnetwork Era. New York: New York University Press, pp. 3-36.

Holt, J. (ed.) (2007). The Daily Show and Philosophy: Moments of Zen in the Art of Fake News. Oxford: Blackwell.

Issers, O. (2014). 'Mediafeiki: mezhdu pravdoj i mistifikatsiej' [Media fakes: Between the truth and mystification]. Kommunikativnye issledovanija [Communication Studies] 2, pp. $112-123$.

Kuipers G. (2008). 'The sociology of humour', in Raskin, V. (ed.), The Primer of Humour Research, Berlin: Mouton de Gryuter, pp. 361-398.

Kotthoff, H. (2002). 'Irony, quotation and other forms of staged intertextuality: Double or contrastive perspectivation in conversation', in Graumann, C. F. \& Kallmeyer, W. (eds.), Perspective and Perspectivation in Discourse, Amsterdam: John Benjamins, pp. 201-233.

Macmillan Dictionary Online (2009-2019). Retrieved from https://www.macmillandictionary.com

Norrick, N. R. (1989). 'Intertextuality in humour'. Humour: International Journal of Humour Research 2 (2), pp. 117-139.

Piégay-Gros, N. (2007). Vvedenie v teoriu intertekstualnosti [Introduction in the theory of intertextuality] (transl. by G. Kosikov, V. Lukasik \& B. Narumov). Moscow: LKI Press.

Rubin, V. L., Conroy, N. J., Chen, Y. \& Cornwell, S. (2016). 'Fake news or truth? Using satirical cues to detect potentially misleading news'. Proceedings of NAACL-HLT 2016. San Diego, California, pp. 7-17.

Scollon, R. (2004). 'Intertextuality across communities of practice', in Moder, C. L. \& Martinovic-Zic A. (eds.), Discourse across Languages and Cultures, Amsterdam: John Benjamins, pp. 149-176.

Simpson, P. (2003). On the Discourse of Satire: Towards a Stylistic Model of Satirical Humour. Amsterdam: John Benjamins.

Tandoc, E. C., Lim, Z. W. \& Ling, R. (2018). 'Defining "fake news": A typology of scholarly definitions'. Digital Journalism 6 (2), pp. 137-153.

Verma, N., Fleischmann, K. R. \& Koltai, K. S. (2017). 'Human values and trust in scientific journals, the mainstream media and fake news'. Proceedings of the Association for Information Science and Technology 54 (1), pp. 426-435. 


\section{Analysed articles}

A 1000000 Rouble banknote to be released. Retrieved from http://smixer.ru/news/a-666.html.

Duterte Supporters Blame Robredo for Earthquakes. Retrieved from https://superficialgazette.wordpress.com/2017/04/08/duterte-supporters-blame-robredofor-earthquakes/.

Duterte Supporters Blame Robredo for Mayon Eruption. Retrieved from https://superficialgazette.wordpress.com/2018/02/16/duterte-supporters-blame-robredomayon-eruption/.

Flustered Father Struggling to Answer All Of Son's Questions About What Catch Is. Retrieved from https://sports.theonion.com/flustered-father-struggling-to-answer-all-of-son-s-ques$1822736902 /$.

Marriages to be prolonged annually. Retrieved from http://smixer.ru/news/a-682.html.

Russian Scientists Demonstrated Their New Invention to the Public. Retrieved from http://smixer.ru/news/a-670.html.

Shocked Vladimir Putin Slowly Realizing He Didn't Conspire with Trump Campaign. Retrieved from https://politics.theonion.com/shocked-vladimir-putin-slowly-realizing-hedidn-t-consp-1833575011

The Russian Government to be bolstered by two African officials. Retrieved from http://smixer.ru/news/a-531.html

Trump Calls Secret Meeting to Power-up for Next Summit. Retrieved from https://www.humortimes.com/68141/trump-next-summit/

Twin earthquakes rock Metro Manila, nearby provinces. Retrieved from http://www.rappler.com/move-ph/issues/disasters/166417-earthquakeph-quake-metromanila-neigboring-provinces?utm_source $=$ twitter\&utm_medium $=$ referral

Vertically Challenged Putin Demands World Leaders Greet Him on Their Knees. Retrieved from https://www.humortimes.com/60309/putin-demands-leaders-get-down-knees/ 